\title{
IMPLEMENTASI 'MASYARAKAT MADANI' BERBASIS KEARIFAN LOKAL DALAM PRAKTIK SOSIAL PONDOK PESANTREN DARUL ULUM BANYUANYAR
}

\author{
MOH. FAIQ \\ Tadris IImu Pengetahuan Sosial, Fakultas Tarbiyah IAIN Madura \\ faiq.secret@gmail.com
}

\begin{abstract}
Abstrak
Artikel ini membuktikan, bahwa pendidikan pesantren memiliki nilai lebih dari pada pendidikan nonpesantren. Hal ini dibuktikan dengan; 1) Peserta didik/santri mampu menerapkan nilai agama dan nilai sosial, 2) Peserta didik /santri mampu menghadapi tantangan era globalisasi dengan tetap mempertahankan nilai-nilai etika dan moral sesuai dengan tuntunan agama, dan 3) Peserta didik /santri mampu berkompetensi dan menghasilkan karya. Tulisan ini menggunakan pisau analisis yang dikemukakan oleh Talcott Parsons melalui teori fungsionalisme struktural; unit tindakan menuju sistem tindakan, yang menjadi faktor pembentuk santri di pondok pesantren dalam merealisasikan nilai-nilai, norma-norma, kesadaran secara kolektif, dan terus melekat dalam diri santri/santri, yang hal tersebut tidak dijamah oleh pendidikan non-pesantren. Penelitian ini menggunakan metodologi kualitatif berupa observasi dan wawancara yang bersifat analisis-diskriptif berdasarkan perspektif sosiologi.

Keyword: kebudayaan pesantren, nilai-nilai, masyarakat madani, santri
\end{abstract}

\begin{abstract}
This article proves, that pesantren education has more value than non-pesantren education. This is proven by; 1) Students / students are able to apply religious values and social values, 2) Students / students are able to face the challenges of the globalization era while maintaining ethical and moral values in accordance with religious guidance, and 3) Students / students are able to be competent and produce creation. This paper uses a knife analysis proposed by Talcott Parsons through the theory of structural functionalism; unit of action towards the system of action, which is a factor forming santri in pondok pesantren in realizing values, norms, collective awareness, and continuing to be inherent in santri / santri, which is not touched by non-pesantren education. This study uses a qualitative methodology in the form of observations and interviews that are descriptive-analysis based on a sociological perspective.
\end{abstract}

Keywords: pesantren culture, values, civil society, santri 


\section{PENDAHULUAN}

Pendidikan pesantren merupakan model pendidikan Islam yang sejak dulu telah diterapkan di Indonesia, bahkan sebelum Indonesia merdeka. Model pendidikan tradisional ini, dipertahankan karena dinilai memiliki pengaruh besar terhadap pembentukan moral. Indonesia lambat laun semakin banyak mendirikan pendidikan pesantren dengan model pedidikan yang berbeda baik itu salaf atau khalaf.

Perkembangan pendidikan yang dipengaruhi oleh perkembangan ilmu dan teknologi, memberikan transformasi baru terhadap model pendidikan pesantren, sebagai respon atas tuntutan zaman. Pondok pesantren saat ini, sebagian menggunakan model pendidikan perpaduan antara tradisional dan modern. ${ }^{1}$ Pendidikan tradisional atau modern dilihat dari bentuk atau pola pengajaran. Pesantren dikatakan memiliki model pendidikan tradisional karena pola pengajarannya berupa pengajian kitabkitab klasik, pengajaran sorogan, bandongan, dan weton dengan materi pelajaran agama. ${ }^{2}$ Pesantren dikategorikan model pendidikan modern karena sistem pengajarannya berupa kelas-kelas yang memuat materi pelajaran umum, seperti eksakta dan sains.

Penggunaan model baik tradisional maupun modern, tidak mempengaruhi orientasi utama pesantren yang berbasis nilainilai (values oriented). Meskipun pada dasarnya pesantren lebih berkonsentrasi dalam bidang keagamaan (diniyah), sekaligus upaya dalam membentuk santri agar sesuai dengan tuntunan agama. Disisi lain, pesantren tetap menjunjung pendidikan santri dalam mengenyam bidang keilmuan non-agama (umum). Keduanya sama-sama dijalankan secara optimal dengan menempatkan keagamaan maupun keilmuan non-agama menjadi sangat penting untuk kemanjuan bangsa.

Perhatian pesantren lebih mengutamakan ilmu sebagai penerapan nilainilai, baik ilmu agama maupun umum. kemampuan penerapan nilai inilah sebagai tolak ukur keberhasilan santri ketika hidup di tengah-tengah masyarakat, dan memiliki

\footnotetext{
${ }^{1}$ Mastuhu, Dimanika Sistem Pendidikan Pesantren: Suatu Kajian tentang Unsur dan Nilai Sistem Pendidikan Pesantren (Jakarta: INIS, 1994), hlm. 170-173

Abd. Halim Soebahar, Modernisasi Pesantren: Transformasi Kepemimpinan Kiai dalam Sistem Pendidikan Pesantren (Yogyakarta: PT. LKIS Printing Cemerlang, 2013), hlm. 47
}

tujuan pokok untuk membentuk pribadi agar memiliki karakter mulia. ${ }^{3}$

Sejauh ini pesantren memiliki keunggulan dalam upaya menanamkan nilainilai. pesantren secara sengaja membentuk sebuah kebudayaan agar senantiasa melekat kedalam kehidupan santri. Kebudayaan pesantren diarahkan untuk penanaman nilai dan norma dalam bentuk regulasi yang bersifat wajib. Bahkan pola ini disebut pola pedidikan Islam yang unik, dan tidak ditemui di negara Islam yang lain kecuali di Indonesia. ${ }^{4}$

Kesengajaan dalam membentuk kebudayaan pesantren ini memiliki potensi pembentukan nilai yang bersifat kontinu dan terintegrasi. Seperti yang dikatakan oleh Paul Rock sebagai "kesengajaan yang dibuat dengan sengaja". ${ }^{5}$ Dengan kata lain, konteks pendidikan pesantren secara sosio-kultural, memiliki kaitan yang sangat erat dengan salah satu teori ilmu sosial fungsionalisme struktural: unit tindakan menuju sistem tindakan.

Kemudian, eksistensi pondok pesantren akhirnya menjadi panutan karena telah terbukti memberikan kontribusi besar bagi pendidikan bangsa, untuk menjadikan warga negara Indonesia menuju masyarakat madani (civil society). Menjadikan warga negara yang memiliki kekuatan spiritual-keagamaan, pengendalian diri, kepribadian, kecerdasan, akhlak mulia serta keterampilan dirinya, masyarakat, bangsa dan negara. ${ }^{6}$

\footnotetext{
${ }^{3}$ Gliuseppe Milan, Educare allincotro la edagoia di martin buber, (Cittanuova, 2000), hlm. 51

4 Said Aqil Siraj, "Visi Pesantren Masa Depan", dalamMakalah Seminar Nasional: Musabaqah al-Qur'an Nasional V Telkom 2005, hlm. 1

${ }^{5}$ Ian Crab, Teori-teori Sosial Modern dari Parsons sampai Habermas, (Jakarta: CV. Rajawali, 1995), hlm. 109

${ }^{6}$ Departemen Pendidikan Nasional Republik Indonesia, Undang-undang Republik Indonesia Nomor 20 tahun 2003 tentang Sistem Pendidikan Nasional (Jakarta: Biro Hukum dan Organisasi Sekretariat Jendral Departemen Pendidikan Nasional, 2003), hlm 6
} 


\section{METODE}

Penelitian ini bertujuan untuk mengangkat transformasi bentuk-bentuk pendidikan Pesantren Darul Ulum Banyuanyar, dengan menggunakan metodologi kualitatif melalui sudut pandang sosiologi. Kajian sosiologi sengaja digunakan untuk mengkaji kehidupan pesantren dalam pembentukan nilai secara kolektif, serta pengaruh terhadap orientasi pendidikan pesantren, utamanya ketika dibenturkan dengan era globalisasi seperti saat ini, dengan upaya mediskripsikan fenomena ${ }^{7}$ yang bersifat inkuiri naturalistik. ${ }^{8}$

Upaya ini bertujuan untuk menilai sejauh mana keberhasilan model pendidikan Pesantren Darul Ulum Banyuanyar. Dengan kata lain, penelitian ini menjadi cakupan penelitian tentang keberhasilan pendidikan sekaligus mencari sisi keunikan dari pesantren ini yang mungkin tidak dimiliki oleh pesantren yang lain. Di samping itu, tiada lain untuk mengukur dan mengevaluasi hasil pendidikan yag ada di Pesantren Darul Ulum Banyunyar.

Data melalui hasil observasi dan wawancara diperoleh secara internal dan eksternal. Kemudian ditelaah melalui perspektif sosiologi dengan menggunakan teori Talcott Parsons. Teori ini menjadi pisau untuk menganalisis faktor-faktor yang mempengaruhi keberhasilan atau kegagalan dari apa yang selama ini diupayakan oleh Pesantren Darul Ulum Banyuanyar. Selain itu, hasil analisis data melalui teori ini juga menjadi instrumen penting dalam mengevaluasi dan menjadikan acuan untuk dijadikan sampel teoritis, yang nantinya bisa diterapkan meskipun di luar konteks pendidikan berbasis pesantren.

Instrumen yang menjadi sumber penelitian adalah pengurus, santri, wali santri, stakeholders dan termasuk warga setempat yang berada di sekitar Pesantren Darul Ulum Banyuanyar, yang secara relfeksi dipengaruhi oleh kehidupan pesantren. Cakupan penelitian ini diharapkan memberikan penjelasanpenjelasan yang luas dengan menggunakan variabel yang berbeda, untuk memperoleh data-data dan temuan-temuan yang kredibel. Selain itu, upaya ini dilakukan dalam rangka

\footnotetext{
7 Sanapiah Faisal, Penelitian Kuaitatif: Dasar-Dasar dan Aplikasi (Malang:YA3,1990), hlm. 22

Lexy J. Moleong, Metodologi Penelitian Kualitatif (Bandung: PT. Remaja Rosdakarya, 2004), hlm. 3
}

Implementasi 'Masyarakat Madani' Berbasis Kearifan Lokal Dalam Praktik Sosial Pondok Pesantren Darul Ulum Banyuanyar

untuk memperdalam pengembangan ilmu-ilmu sosial. $^{9}$

\section{HASIL DAN PEMBAHASAN \\ Sejarah Kepemimpinan Pesantren}

K. Itsbat bin Ishaq bin Hasan bin Abdurrahman (Kiai Abdurrahman adalah menantu Sunan Giri Gresik), ${ }^{10}$ mendirikan Pesantren Banyuanyar di desa Poto'an Dajah Palengaan Pamekasan Madura pada tahun 1787 M. Filosofi nama "Banyuanyar" sendiri mempunyai arti "sumber air", karena terdapat sumur tua yang airnya dijadikan sumber kehidupan dan begitu besar manfaatnya sampai saat ini. Sedangkan nama "Darul Ulum" adalah nama yang secara formal dicetuskan sekitar tahun 1980-an.

Di tempat itulah K. Itsbat mendidik santri dengan istiqomah. Beliau merupakan sosok kiai yang sangat terkenal akibat kedzhulan serta kearifan keilmuannya yang kemudian melahirkan ulama-ulama besar yang tersebar di Madura-Jawa. Oleh sebab itu, Pesantren Darul Ulum dimasukkan kedalam 5 pesantren tertua di Indonesia. ${ }^{11}$ Salah satu ulama yang masih merupakan satu dulur (Madura: Silsilah, keluarga, ikatan darah) adalah RKH. Abdul Majid yang masih merupakan cucu dari $\mathrm{K}$. Itsbat. Beliau mendirikan pesantren Bata-bata pada tahun 1943, yang terletak sekitar $2 \mathrm{~km}$ sebelah selatan pesantren Darul Ulum Banyuanyar.

K. Itsbat sebagai pemimpin pertama wafat pada tahun $1868 \mathrm{M}$, maka kepemimpinan digantikan kepada putra tertuanya yaitu RKH. Abdul Hamid sebagai pemimpin generasi kedua (1868-1933). RKH. Hamid dikenal sebagai sosok kiai yang cerdas dan mimiliki kesemangatan mendalam untuk pendidikan dan ilmu pengetahuan. Selama di Mekkah, ia merupakan murid ulama terkemuka Syaikh Nawawi al-Bantani. ${ }^{12}$ Namun pada tahun 1933, RKH. Hamid kembali ke Mekkah untuk menunaikan ibadah haji dan tidak lama setelah itu, beliau wafat dan dimakamkan di muqrabah ma'la. ${ }^{13}$

RKH. Abdul Hamid wafat dan pemimpin generasi ketiga berpindah kepada putranya RKH. Abdul Majid pada tahun 1933-1943. RKH. Abdul Majid belajar di Mekkah cukup

9 Burhan Bungin, Analisis Data Penelitian Kualitatif, (Jakarta: Raja Grafindo Persada. 2005), hlm. 23

10 Buku Santri Lembaga Pendidikan Islam Darul Ulum Banyuanyar Pamekasan, 2014

Kompri, Manajemen \& Kepemimpinan Pondok Pesantren (Jakarta: Prenadamedia Group, 2018), hlm 24

${ }^{12}$ Halim Soebahar, Modernisasi Pesantren. hlm. 100

13 "Biografi KH. Abdul Majid" dalam Majalah Fatwa (Pamekasan: PP. Darul Ulum Banyuanyar, Edisi 03/th. 11/Agustus-September 1996), hlm 19 
lama sebagaimana yang pernah dilakukan oleh sang ayah untuk memperdalam ilmu-ilmu agama. Selain itu, RKH. Abdul Majid masih merupakan murid dari Syaikhona Muhammad Kholil pengasuh Pesantren Demangan Bangkalan, yang merupakan kiai besar dan merupakan keturunan Sunan Gunung Jati, seorang Wali Songo di Pulau Jawa. ${ }^{14}$

$\mathrm{RKH}$. Abdul Majid kemudian mendirikan Pesantren Bata-bata setelah 11 tahun menjadi pengasuh Pesantren Darul Ulum Banyuanyar. Sehingga secara otomatis, tampuk kepemimpinan digantikan oleh RKH. Baidhawi (1943-1966). Kiai sebagai pemimpin generasi keempat ini, dikenal sebagai sosok yang 'alim dan senang dalam organisasi. Hal ini dibuktikan dengan upaya $\mathrm{RKH}$. Baidhawi yang banyak merintis madrasah-madrasah diniyah, suatu gebrakan untuk membuka gerbong pendidikan di masa itu.

Setelah menjadi pengasuh pesantren kurang lebih 23 tahun, akhirnya kepemimpinan diserahkan kepada RKH. Abdul Hamid Bakir. Sosok kiai pemimpin generasi kelima ini, dikenal dengan kejunelannya (junel: sakti mandraguna). Selama di Mekkah, beliau dibimbing langsung oleh ulama terkemuka yaitu Syaikh Alawi Al-Maliki. Khalil Asyari yang merupakan mantan ketua pengurus pesantren menilai bahwa Keberadaan RKH. Abdul Hamid Bakir selama menjadi pengasuh di pesantren, memberikan banyak kesejukan batin, sehingga kehadirannya senantiasa masih dirindukan hingga saat ini.

Pada masa RKH. Abdul Hamid Bakir inilah, sistem kaloraan ${ }^{15}$ di Pesantren Darul Ulum diterapkan. Sistem kaloraan ini membantu para santri untuk belajar dan mengenal aspek-aspek yang perlu diterapkan di pesantren, khususnya dalam aspek ubudiyah. Selain itu, kaloraan juga menjadi sumber belajar ketika RKH. Abdul Hamid Bakir berpergian. Bepergian merupakan salah satu kebiasaan RKH. Abdul Hamid Bakir dan akan langsung memberikan pengajian kepada santri setelah beiau kembali di waktu dan jam berapapun.

RKH. Abdul Hamid Bakir wafat pada tahun 1980 dan kepemimpinan pesantren jatuh kepada RKH. Muhammad Syamsul Arifin sejak 1980 hingga sekarang. Peralihan kepemimpinan ini memberikan nuansa yang berbeda karena RKH. Muhammad bukan

\footnotetext{
${ }^{14}$ Ibnu Assayuthi Arrifa'i, Korelasi Syaikhona Muhammad Kholil Bangkalan dan NU; Mengenang dan Menghayati Perjuangan Sang Inspirator, (Jakarta: Al-haula press, 2010) hlm. 46

15 "Kaloraan" yaitu sejumlah santri senior yang bertugas memberikan bimbingan kepada santri secara teratur (organizing)
}

merupakan keturunan atau silsilah secara langsung, seperti peralihan kepempinan sebelumnya. Namun, Kiai Abdul Latif yang merupakan ayah dari RKH. Muhammad masih memiliki pertautan silsilah dengan pendiri Pesantren Banyuanyar yang marupakan keturunan Buyut Congkop Pakes.

Dari seluruh pemimpin Pesantren Banyuanyar yang telah dipaparkan, para kiai memiliki perbedaan dalam memajukan pesantren. Namun ada persamaan yang dimiliki oleh semua kiai dan memiliki pengaruh yang besar, yaitu sifat kharismatik. Semua kiai memiliki sifat kharismatik dan dirasakan oleh santrinya. Seperti yang dikatakan oleh Max Weber, kharismatik adalah pemimpin yang ideal dan jenius dan mampu menerobos kebekuan sosial. Pemimpin kharismatik memiliki daya yang kuat, perihal norma dan nilai-nilai bagi warga masyarakat $^{16} \mathrm{di}$ pesantren.

Selain sifat kharismatik yang dimiliki oleh kiai, darah dan gelar yang kiai miliki menunjukkan identitas kebangsawanan. Identitas kebangsawanan yang dimiliki oleh kiai sering diletakkan di awal nama dan gelar lainnya. Contohnya adalah RKH (Raden Kiai Haji) dan RPKH (Raden Panji Kiai Haji) yang umum digunakan di Madura dan di beberapa daerah Tapal Kuda di Jawa Timur. Gelar raden di atas umumnya digunakan untuk menunjukkan status kebangsawanan yang dimiliki seorang kiai. ${ }^{17}$

\section{Table 1. Nama-nama Pengasuh Pesantren Darul Ulum Banyuanyar berdasarkan Periode}

\begin{tabular}{|l|l|l|}
\hline No & Nama & Periode \\
\hline 1. & $\begin{array}{l}\text { K. Itsbat Bin Ishaq Bin } \\
\text { Hasan Bin Abdurrahman }\end{array}$ & $1788-1868$ \\
\hline 2. & $\begin{array}{l}\text { RKH. Abdul Hamid Bin } \\
\text { Itsbat }\end{array}$ & $1868-1933$ \\
\hline 3. & $\begin{array}{l}\text { RKH. Abdul Majid Bin Abdul } \\
\text { Hamid }\end{array}$ & $1933-1943$ \\
\hline 4. & $\begin{array}{l}\text { RKH. Baidhawi Bin Abdul } \\
\text { Hamid }\end{array}$ & $1943-1966$ \\
\hline 5. & $\begin{array}{l}\text { RKH. Abdul Hamid Bakir bin } \\
\text { Abdul Majid }\end{array}$ & $1966-1980$ \\
\hline 6. & $\begin{array}{l}\text { RKH. Muhammad Syamsul } \\
\text { Arifin Bin KH. Abdul Lathif }\end{array}$ & $\begin{array}{l}1980- \\
\text { sekarang }\end{array}$ \\
\hline
\end{tabular}

\section{Bentuk Pendidikan Pesantren}

Pendidikan Islam nusantara telah berlangsung sejak masa perjuangan yang

\footnotetext{
${ }^{16}$ Surjono Sukanto, Sosiologi suatu Pengantar, (Jakarta: Ul Press, 1982), hlm. 75

17 Kuntowijoyo, Perubahan Sosial dalam Masyarakat Agraris Madura 1850-1940, (Yogyakarta: Matabangsa, 2002), hlm. 226
} 
terselenggara di surau-surau secara nonformal, hingga secara formal masuk sebagai bagian dari pada mata pelajaran sekolahsekolah. ${ }^{18}$ Pesantren Darul Ulum Banyuanyar yang merupakan pesantren sejak dulu, telah merumuskan visi dan misi terhadap tujuan berdirinya sejak awal. Keduanya memiliki kaitan dengan pendidikan Islam di Indonesia. Visi Pesantren Darul Ulum berbunyi "Lahirnya generasi muslim beraklaqul karimah, berilmu amaliyah dan beramal ilmiah". Sedangkan Misi Pesantren Darul Ulum adalah "Menyelenggarakan pendidikan".

Bentuk visi dan misi tersebut diterjemahkan kedalam bentuk institusi formal maupun non-formal. Pembentukan dan pengelolaan lembaga pendidikan merupakan sebagai pembakuan norma dan nilai-nilai. Institusi yang berkembang sesuai dengan tuntan zaman merupakan transformasi model pendidikan dari salaf menuju khalaf.

Kegiatan pesantren meliputi dua bentuk. Bentuk yang pertama yakni pengajaran yang dilaksanakan langsung di sekitar asrama, aula, dan masjid. Kegiatan ini meliputi pengajaran ilmu agama seperti nahwu, sorrof, dan juga tafsir al-quran. Selain itu, terdapat kegiatan wajib berbentuk tindakan yang berkaitan dengan nilai agama, seperti sholat berjemaah, mengaji al-quran dan termasuk membaca sholawat setiap malam jumat. Kategori pertama ini masih menggunakan model pendidikan tradisional. Hal ini digambarkan lewat kegiatan dengan menggunakan metode sorogan ${ }^{19}$ dan majlis taklim.

Bentuk yang kedua adalah pengajaran yang dilaksanakan di sekolah. Pengajaran ini sama dengan pendidikan formal. Terdapat hampir semua jenjang pendidikan yang berada di Pesantren Darul Ulum, mulai dari RA, TPA, PAUD, MI, MTs, MA, dan termasuk Perguruan Tinggi. Dimana, pendidikan formal ini termasuk pendidikan yang diwajibkan kepada santri sesuai dengan jenjangnya. Bentuk pendidikan model ini disebut pendidikan modern karena menggunakan metode yang diintrodusir kedalam institusi dengan menggunakan pendekatan ilmiah.

Lembaga non-formal Pesantren Darul Ulum Banyuanyar disediakan untuk santri dalam mengasah keterampilan dan kemampuan softskill. Santri dapat memilih

\footnotetext{
${ }^{18}$ Atiqullah, Manajemen dan Kepemimpinan Pendidikan Islam, (Surabaya: Pena Sasabila, 2012), hlm 25

${ }_{19}$ Mujamil Qomar, Pesantren dari Transformasi Metodologi Menuju Demokatisasi Institusi, (Jakarta: Penerbit Erlangga, 2007), hlm. 142.
}

Implementasi 'Masyarakat Madani' Berbasis Kearifan Lokal Dalam Praktik Sosial Pondok Pesantren Darul Ulum Banyuanyar

kegiatan-kegiatan pengembangan sesuai dengan minat dan bakat santri. Ada sekitar 40an kegiatan yang terdapat di pesantren ini, dengan tema dan orientasi yang beragam. Seperti kepenulisan, seni, pramuka, kesehatan dan termasuk kebahasaan.

Pendidikan yang diselenggarakan oleh Pesantren Darul Ulum Banyuanyar merupakan sebagai bentuk dari visi dan misi pesantren. Pesantren mewajibkan santri untuk mengikuti kegiatan pondok, sekaligus juga mewajibkan untuk mengikuti kegiatan di sekolah. Namun pada intinya tujuan utama pesantren ialah penanaman nilai-nilai. Kegiatan yang bersifat wajib menjadi rambu-rambu lalu lintas (trafic light) ${ }^{20}$ bagi santri. Rambu-rambu ini yang disebut sebagai norma. Norma merupakan cara untuk membentuk nilai, individu maupun kelompok. Nilai memililki sifat yang tidak nampak, maka norma berperan untuk memelihara dan melindunginya. Nilai-nilai yang sengaja diupayakan adalah nilai agama, nilai sosial, nilai hidup sederhana, nilai kearifan lokal dan termasuk nilai untuk memperjuangkan ilmu yang barokah. ${ }^{21}$

Keyakinan santri terhadap ilmu yang barokah menjadi kekuatan dari setiap perjuangan yang dilakukan santri selama di pesantren. kekuatan ini menjadi motivasi intrinsik yang mampu mengamalkan ajaran agama dan ketaatan kepada Allah SWT. Karena pada hakikatnya barokah adalah "albarokatuhu tuzidukum fi thoah" (barokah menambah ketaatan kepada Allah) ${ }^{22}$. Bentuk barokah pun tidak selamanya berbetuk dengan kenikmatan, namun terkadang manusia diuji dengan kesulitan seperti yang diberikan kepada Nabi Ayyub AS. Tentang rasa sakitnya yang lama, namun ternyata rasa sakit itu justru menambah keimanannya.

\section{Teori Fungsionalisme Struktural}

Fungsionalisme struktural adalah teori yang memandang bahwa masyarakat diatur oleh sistem yang menyebabkan keterkaitan antara individu dengan indvidu yang lain. Masing-masing memiliki fungsi yang berbeda. Tujuan pendidikan yang ada di pesantren bergantung pada setiap fungsi struktur dalam menempatkannya secara tepat. Teori yang ditekankan oleh Talcott Parsons ini mengarah kepada pengertian bahwa masyarakat sebagai

\footnotetext{
20 Antonius Atosokhi Gea, Relasi dengan Sesama Character Building II, (Jakarta: PT. Flex Media Komputindo, 2005), hlm. 154

${ }^{21}$ Wawancara dengan Ahmad Rofiki (Asatid Pesantren Darul Ulum Banyuanyar), pada tanggal 21 Sep 2018, jam 12.45

${ }^{22}$ Kiai Abdullah Afif, Pustaka IImu Sunni Salafiyah-KTB, (Yogyakarta: PISS-KTB, 2015), hIm. 5071.
} 
suatu sistem sosial, yang secara fungsional terintegrasi kedalam bentuk keseimbangan (equilibrium). ${ }^{23}$

Arti masyarakat secara umum adalah sekumpulan individu yang berada dalam satu wilayah atau lingkungan yang memiliki sistem, aturan dan norma. hal itu ditunjukkan atas interakasi-interaksi yang kontinu (al-ahqat addaimah), ${ }^{24}$ yang telah melekat dan menjadi kebiasaan, tradisi dan kebudayaan. Kebudayaan tersebut dibentuk melalui asas normatif dan deskriptif.

Kehidupan di pesantren telah memenuhi syarat untuk disebut sebagai masyarakat. $\mathrm{Di}$ dalamnya memuat sekumpulan individu yang berinteraksi dan membentuk suatu kebudayaan. Kebudayaan pesantren dibentuk atas dasar sistem dengan struktur yang memiliki fungsi yang berbedabeda, yang bekerja dari unit tindakan menuju sistem tindakan. dalam konteks Pesantren Darul Ulum, contohnya adalah pengasuh, pengurus, dan santri yang termasuk variabel yang disebut sebagai unit tindakan, sedangkan realisasi dari bentuk tindakan secara kolektif, berubah menjadi sistem tindakan yang terformulasikan.

Talcott Parsons dengan teori fungsionalisme struktural: unit tindakan menuju sistem tindakan ini, memberikan penjelasan bahwa santri tidak hanya hidup dengan tujuannya, namun santri memiliki sinergi dengan struktur yang lain, kepada kiai, pengurus, ustad, santri, dan termasuk kabuleen (pelayan kiai dan santri). Meskipun masing-masing struktur memiliki fungsi yang berbeda, namun perbedaan tersebut bukan menjadi hambatan untuk tercapainya tujuan pesantren secara kolektif, melainkan harus dimainkan dan diperankan sebagai bentuk mekanisme dari eksistensi pesantren.

Kiai memiliki banyak peranan. Kiai sebagai pengasuh, pengajar, pendidik, motivator dan termasuk yang bertanggung jawab atas segala hal yang terjadi di pesantren. Sedangkan ustad atau pengurus bertugas untuk menformulasikan instruksi kiai, kedalam bentuk regulasi tertulis. Regulasi ini akan menjadi norma, yang disertai dengan sanksi jika santri merabrak norma yang telah ditetapkan. Kemudian santri menerjemahkan norma kedalam bentuk prilaku, sikap, dan kesadaran kolektif. Melalui pendekatan structural-functional approach ini, santri tidak

\footnotetext{
${ }^{23}$ I.B Wirawan, Teori-teori Sosial dalam Tiga Paradigma, Fakta Sosial, Definisi Sosial, dan Perilaku Sosial, (Jakarta: Prenandamedia Group, 2015), hlm 41.

${ }^{24}$ Saktiyono B. Purwoko, Psikologi Islami Teori dan Penelitian, (Bandung: Saktiyono Press, 2012), hlm. 71
}

lagi dipandang secara individu melainkan kelompok.

Kajian fungsionalisme struktural kemudian menelusuri yang menjadi unit tindakan atas pengaruh utama keberhasilan Pesantren Darul Ulum Banyuanyar. Selain kiai mempunyai sifat kharismatik, kiai juga dinilai memiliki sifat karomah yang kerap kali menjadi faktor tertentu dalam kepemimpinan. ${ }^{25} \mathrm{Hal}$ ini ditandai dengan begitu takdimnya masyarakat kepada sosok kiai. Masyarakat menjadikan kiai sebagai panutan, tempat untuk mencari ilmu dan meneladani setiap akhlak yang dicontohkan. Kiai dijadikan sebagai sumber inspirasi, dalam urusan jodoh, membagi harta pusaka sesama ahli warisnya, bahkan dalam menentukan lapangan pekerjaannya pun, seorang santri merasakan ada kewajiban moral untuk berkonsultasi dan mengikuti petunjuk-petunjuk kiainya. ${ }^{26}$

Sistem tindakan menurut Parsons ditandai dengan bentuk menformulasikan norma. Dimana bentuk ini berupa regulasi tertulis. Meskipun regulasi tertulis ini, bukanlah suatu hal yang menjadi faktor utama dalam menggerakkan kesadaran santri secara kolektif. $^{27}$ Hal yang mendorong santri justru sikap takdim yang mendalam kepada kiai. Ini membuktikan bahwa santri telah sampai kepada nilai-nilai luhur yang diharapkan pesantren. Ketakdiman ini ditunjukkan salah satunya adalah, ketika kiai keluar bepergian dan melewati asrama santri, santri seketika berdiri sambil menunduk dan menghadapkan tubuhnya kepada kiai namun mengarahkan pandangannya ke bawah. Sifat takdim ini telah melekat dan menjadi kunci untuk mendapatkan ilmu yang barokah.

Norma yang demikian tidak secara langsung diterapkan kepada ustad atau guru yang lain. Norma ini hanya berlaku kepada kiai atau kepada putra dan kerabat kiai, yang biasanya diekspresikan dengan sebutan"lora", gus (Jawa), (noble, gentle) ${ }^{28}$ untuk putra lakilaki, dan sebutan nyai atau neng untuk putri. Karena pada hakikatnya, pengurus, ustad dan guru masih diposisikan sebagai santri. Namun mereka telah menjalani pengabdian dan memilih untuk kembali ke pesantren untuk mengabdi dengan cara menjadi pengurus atau tinggal di kaloraan.

\footnotetext{
${ }^{25}$ Atiqullah, Perilaku kepemimpinan Kolektif Pesantren, (Surabaya: Pustaka Radja, 2016), hlm. 29 Abdurrahman Wahid, Bunga Rampai Pesantren, (Jakarta: CV Dharma Bhakti, 1981), hlm. 14.

27 Wawancara dengan Aminullah (Pengurus Pesantren), pada tanggal 24 Sep 2018

${ }^{28}$ Nurcholish Madjid, Bilik-Bilik Pesantren; Sebuah Potret Perjalanan (Jakarta: Paramadina, 1997), hlm. 24.
} 
Dari fenomena yang telah dipaparkan diatas, kehidupan pesantren dinilai telah memenuhi persyaratan dengan apa yang disebut Parsons melalui fungsionalisme struktural. Syarat ini merupakan sistem yang tetap bertahan dari berbagai perubahan internal maupun eksternal. Terdapat empat persyaratan fungsional yang dikemukakan oleh Parsons; adaptasi, goal attainment, integrasi and latency (latent pattern maintenance). Semua sistem ini, oleh Parsons disebut dengan istilah AGIL, melalui AGIL inilah kemudian dikembangkan pemikiran mengenai struktur dan sistem. ${ }^{29}$

Table 2. Persyaratan Fungsionalisme Struktural Talcott Parsons

\begin{tabular}{|c|c|l|}
\hline No & Sistem & \multicolumn{1}{c|}{ Persyaratan } \\
\hline 1. & Adaptasi & $\begin{array}{l}\text { Masyarakat sebagai } \\
\text { sistem harus } \\
\text { memiliki daya } \\
\text { adaptasi yang tinggi } \\
\text { terhadap berbagai } \\
\text { kondisi dan } \\
\text { perubahan. }\end{array}$ \\
\hline 2. & $\begin{array}{c}\text { Goal Attainment } \\
\text { (Perumusan } \\
\text { Tujuan) }\end{array}$ & $\begin{array}{l}\text { Sistem harus } \\
\text { merumuskan tujuan } \\
\text { utamanya. }\end{array}$ \\
\hline 3. & $\begin{array}{l}\text { Integrasi } \\
\text { Sistem harus } \\
\text { mampu mengelola } \\
\text { hubungan antar } \\
\text { elemen dan antar 3 } \\
\text { komponen syarat ini } \\
\text { demi kelangsungan } \\
\text { sistem tersebut. }\end{array}$ \\
\hline 4. & $\begin{array}{c}\text { Latency (nilai-nilai } \\
\text { kolektif) }\end{array}$ & $\begin{array}{l}\text { Sistem harus } \\
\text { membuat dan } \\
\text { memelihara niai- } \\
\text { nilai yang dimiliki } \\
\text { bersama sebagai } \\
\text { kesadaran kolektif. }\end{array}$ \\
\hline
\end{tabular}

Table 3. Penjelasan AGIL, Fungsionalisme Struktural Talcott Parsons

\begin{tabular}{|c|c|l|}
\hline No & Sistem & \multicolumn{1}{c|}{ Penjelasan } \\
\hline 1. & Adaptasi & $\begin{array}{l}\text { Ditujukan untuk } \\
\text { memperoleh sumber } \\
\text { daya yang memadai } \\
\text { dari lingkungan sekitar } \\
\text { dan mendistribusikan } \\
\text { keseluruh sistem }\end{array}$ \\
\hline 2. & $\begin{array}{c}\text { Goal Attainment } \\
\text { (Perumusan } \\
\text { Tujuan) }\end{array}$ & $\begin{array}{l}\text { Ditujukan untuk } \\
\text { menformulasikan } \\
\text { tujuan utama dari } \\
\text { suatu sistem }\end{array}$ \\
\hline 3. & Integrasi & $\begin{array}{l}\text { Dipahami sebagai } \\
\text { upaya } \\
\text { mengkordinasikan, } \\
\text { mengatur hubungan }\end{array}$ \\
\hline
\end{tabular}

${ }^{29}$ Andi Rusdi Maidin, Model Kepemimpinan Uwatta dalam Komunitas Tolotang Benteng, (Makasar: CV Sah Media, 2017), hlm. 146

\begin{tabular}{|c|c|c|}
\hline & & $\begin{array}{l}\text { antara elemen dan } \\
\text { sistem }\end{array}$ \\
\hline 4. & $\begin{array}{l}\text { Latency (nilai- } \\
\text { nilai kolektif) }\end{array}$ & $\begin{array}{l}\text { Pendidikan, agama } \\
\text { dan } \\
\text { kiai/ustad/keluarga } \\
\text { berperan mentransfer } \\
\text { nilai kolektif yang } \\
\text { dibutuhkan untuk } \\
\text { kelangsungan } \\
\text { masyarakat melalui } \\
\text { proses: Sosialisasi- } \\
\text { institusionalisasi- } \\
\text { internalisasi }\end{array}$ \\
\hline
\end{tabular}

\section{Kondisi Pesantren di Era Globalisasi}

Kehadiran teknologi informasi dan komunikasi telah mempercepat akselerasi proses globalisasi. Globalisasi menyentuh aspek penting kehidupan. Globalisasi menciptakan berbagai tantangan dan permasalahan baru yang harus dijawab, dipecahkan dalam upaya memanfaatkannya untuk kepentingan kehidupan. Demikian juga terhadap pendidikan. ${ }^{30}$ Meskipun pada kenyataannya, globalisasi tidak membuat manusia semakin terbuka untuk menghargai dan meghormati pihak lain dengan latar belakang berbeda.

Pesantren Darul Ulum menerapkan prinsip "almuhâfazhah 'alâ‘al-qadîm al-shâlih wa al-akhdz bi al-jadîd al-ashlah" (memelihara nilai-nilai budaya klasik yang baik, dan mengambil nilai-nilai budaya baru yang dianggap lebih bermanfaat). Pesantren selama ini telah menyediakan pendidikan untuk meningkatkan kemampuan santri di bidang teknologi. Pendidikan formal seperti SMK dan Teknik Jaringan, menjadi salah satu bukti bahwa pendidikan pesantren menginginkan santri yang kompetetif, tidak gaptek (gagap teknologi), serta mampu beradaptasi dengan tuntutan zaman.

Selain pendidikan formal seperti SMK dan Teknik Jaringan, Pesantren Darul Ulum juga memberdayakan kegiatan yang bersifat non-formal untuk kemajuan santri di bidang teknologi. Pesantren mendirikan studio photo, kursus komputer, dan juga saluran radio. Dimana, hal itu didasari atas perkembangan arus informasi dan komunikasi. Dari sini sudah jelas, bahwa pendidikan Pesantren Darul Ulum Banyuanyar sudah mulai menyiapkan sumber daya manusia dan harus memberikan bekal terhadap santri agar dapat mengelola,

30 Sunda Ariana, Manajemen Pendidikan: Peran Pendidikan dalam Menanamkan Budaya Inovatif dan Kompetetif, (Yogyakarta: Andi, 2017), hlm. 46.

31 Josef P. Widyatmadja, Kebebasan dan Globalisasi dalam Diplomasi, (Yogyakarta: Penerbit Kanisius, 2009), hlm. 93. 
menyesuaikan, dan mengembangkan apa yang diterima melalui arus informasi itu. ${ }^{32}$ Sejauh ini, pesantren hanya mengembangkan bentuk teknologi yang betul-betul memberikan manfaat dalam meningkatan sumber daya manusia. Pesantren tidak membebaskan santri secara penuh terhadap arus globalisasi, hal ini dibuktikan dengan tidak diperbolehkannya santri menggunakan internet di pesantren.

Pesantren Darul Ulum Banyuanyar melarang santri membawa alat-alat teknologi yang tidak memberikan manfaat secara kolektif. Seperti handphone, laptop, televisi dan juga speaker aktif. la dianggap sebagai alat yang mempengaruhi kegagalan tujuan belajar santri secara individual. Namun terdapat pengecualian, apabila penggunaan teknologi itu memiliki kaitan dengan tujuan pembelajaran. Lembaga sekolah telah menggunakan Proyektor LCD sebagai media untuk belajar, penggunaan komputer bagi ustad atau guru untuk membuat dokumen, dan termasuk penggunaan internet sebagai mobilitas pendidikan yang terkoneksi dengan pemerintah secara online. ${ }^{33}$

\section{Kebudayaan Pesantren menuju Masyarakat Madani}

Kebudayaan secara umum berasal dari kata Sanskerta buddhayah, ialah bentuk jamak dari buddhi yang berarti "budi" atau "akal". Demikian kebudayaan itu diartikan sebagai "hal-hal yang bersangkutan dengan budi dan akal". ${ }^{34}$ Raymond Williams juga menjelaskan bahwa kebudayaan adalah mengenai perkembangan intelektual, spiritual dan estetik individu dan kelompok. dimana hal itu digambarkan melalui seluruh cara hidup, aktifitas, kepercayaan dan kebiasaan seseorang.

Gambaran kebudayaan yang dipaparkan tadi tidak jauh berbeda dengan kebudyaan yang ditemukan di Pesantren Darul Ulum Banyuanyar. Perbedaan antara pengertian kebudayaan secara umum dan kebudayaan pesantren, yaitu terletak kepada nilai-nilai yang sengaja dibiasakan. Kebudayaan pesantren fokus terhadap nilai-

\footnotetext{
32 Jusuf Amir Feisal, Reorientasi Pendidikan Islam, (Jakarta: Gema Insani Press, 1995), hlm. 131.

${ }_{33}$ Wawancara dengan Baidhowi (Pengurus SMK Darul Ulum Banyuanyar), pada tanggal 28 Sep 2018 di Pesantren Banyuanyar

${ }_{34}$ Koentjaraningrat Pembangunan, (Jakarta: Gema Insani, 2004), hlm. 9
}

nilai agama dan sosial yang sesuai dengan ajaran Islam. Kebudayaan pesantren mengarah kepada etika santri yang pada akhirnya berpotensi membentuk masyarakat madani. Karena masyarakat madani adalah masyarakat etis ${ }^{35}$ dan kunci terwujudnya suatu masyarakat madani adalah pendidikan. ${ }^{36}$

Pesantren Darul Ulum secara terangterangan, mengarahkan santri untuk memiliki nilai, ini dilakukan secara berulang-ulang, hingga menempel dan melekat sebagai pelestarian watak dan budaya manusia. ${ }^{37}$ Disamping itu, Pesantren Darul Ulum Banyuanyar pun secara keras memproteksi santri untuk tidak menabrak nilai, seperti tindak kriminalitas, asusila, instabilitas sosial, dan perpecahan akibat perbedaan pendapat. Dengan kata lain, Pesantren Darul Ulum memasukkan nilai-nilai kebangsaan dan semangat nasionalisme.

Masyarakat madani dicirikan sebagai masyarakat yang beradab, memiliki sikap toleran, menghargai pendapat, memliki nilai agama, sosial dan kebangsaan. Disamping itu membentuk masyarakat yang terbuka dan memberikan hak yang sama untuk berkompetensi dalam menciptakan karya. Sehingga dari nilai-nilai tersebut, diharapkan santri mampu memiliki ruang (space) partisipasi demokrasi bangsa. Dimana demokrasi dimaknai sebagai wujud untuk menciptakan civil society. ${ }^{38}$

\section{PENUTUP}

Dari hasil peneletian ini dapat disimpulkan bahwa pesantren memiliki nilai lebih daripada pendidikan non-pesantren. Pendidikan pesantren mengarah kepada pembentukan nilai-nilai. Nilai-nilai yang lahir dari pendidikan pesantren, akan terus melekat kepada santri sampai kapanpun. Pesantren tidak hanya memberikan ilmu pengetahuan, namun pembentukan nilai-nilai agama, nilai sosial, etika, moral di tengah masyarakat.

Kajian melalui perspektif sosiologi ini, memberikan gambaran bahwa sebenarnya masyarakat tidak hidup secara alamiah saja, melainkan sesuai dengan teori fungsionalisme struktural, bahwa dapat membawa masyarakat menuju kehidupan yang terarah, tersistem, dan terikat norma yang memiliki nilai-nilai

\footnotetext{
${ }^{35}$ Lihat tulisan Sukidi, "Membangun Masyarakat Madani", KOMPAS, 19 April 1998

${ }^{36}$ H.A.R. Tilaar, Beberapa Agenda Reformasi Pendidikan Nasional, (Magelang: Tera Indonesia, 1998), hlm. 291.

${ }^{37}$ J. Milton Yinger, The Scientific Study Religion, (New York: Macmillan, 1970), hlm. 5

38 Aim Abdulkarim, Pendidikan Kewarganegaraan, (Bandung: PT Grafendo Media, 2004), hlm. 24
} 
(values). Nilai-nilai harus sengaja dibawa dan ditampilkan kepada masyarakat, sabagai awal dari bentuk perubahan paradigma, kebiasaan dan kebudayaan.

Oleh karena itu santri memiliki tugas di tengah masyarakat untuk membawa nilai-nilai tersebut, dan menjadikan nilai itu sebagai sistem tindakan. Artinya, kehadiran santri di Indonesia diharapkan semakin banyak. Kehadiran santri yang semakin banyak, akan dengan mudahnya membentuk kebudayaan yang sarat denga nilai-nilai, hingga akhirnya bergeser dan membentuk masyarakat madani.

\section{DAFTAR PUSTAKA}

Abdulkarim, Aim. 2004. Pendidikan Kewarganegaraan. Bandung: PT Grafendo Media.

Afif, Kiai Abdullah. 2015. Pustaka IImu Sunni Salafiyah-KTB. Yogyakarta: PISS-KTB.

Arrifa'i, Ibnu Assayuthi. 2010. Korelasi Syaikhona Muhammad Kholil Bangkalan dan NU; Mengenang dan Menghayati Perjuangan Sang Inspirator. Jakarta: Al-haula press.

Ariana, Sunda. 2017. Manajemen Pendidikan: Peran Pendidikan dalam Menanamkan Budaya Inovatif dan Kompetetif. Yogyakarta: Andi.

Atiqullah. 2012. Manajemen dan Kepemimpinan Pendidikan Islam. Surabaya: Pena Sasabila.

Atiqullah. 2016. Perilaku kepemimpinan Kolektif Pesantren. Surabaya: Pustaka Radja.

Buku Santri 2014 Lembaga Pendidikan Islam Darul Ulum Banyuanyar.

Bungin, Burhan. 2005. Analisis Data Penelitian Kualitatif. Jakarta: Raja Grafindo Persada.

Crab, Ian. 1995. Teori-teori Sosial Modern dari Parsons sampai Habermas. Jakarta: CV. Rajawali.

Departemen Pendidikan Nasional Republik Indonesia. 2003. Undang-undang Republik Indonesia Nomor 20 tahun 2003 tentang Sistem Pendidikan Nasional. Jakarta: Biro Hukum dan Organisasi Sekretariat Jendral Departemen Pendidikan Nasional.

Faisal, Sanapiah. 1990. Penelitian Kuaitatif: Dasar-Dasar dan Aplikasi. Malang:YA3.
Implementasi 'Masyarakat Madani' Berbasis Kearifan Lokal Dalam Praktik Sosial Pondok Pesantren Darul Ulum Banyuanyar

Feisal, Jusuf Amir. 1995. Reorientasi Pendidikan Islam. Jakarta: Gema Insani Press.

Gea, Antonius Atosokhi. 2005. Relasi dengan Sesama Character Building II. Jakarta: PT. Flex Media Komputindo.

Koentjaraningrat. $2004 . \quad K e b u d a y a a n$ Mentalitas dan Pembangunan. Jakarta: Gema Insani.

Kompri. 2018. Manajemen \& Kepemimpinan Pondok Pesantren. Jakarta: Prenadamedia Group.

Kuntowijoyo. 2002. Perubahan Sosial dalam Masyarakat Agraris Madura 1850-1940. Yogyakarta: Matabangsa.

Madjid, Nurcholish. 1997. Bilik-Bilik Pesantren; Sebuah Potret Perjalanan. Jakarta: Paramadina.

Maidin, Andi Rusdi. 2017. Model Kepemimpinan Uwatta dalam Komunitas Tolotang Benteng. Makasar: CV Sah Media.

Majalah Fatwa. 1996. Biografi KH. Abdul Majid. Pamekasan: PP. Darul Ulum Banyuanyar (Edisi 03/th. 11/AgustusSeptember 1996).

Mastuhu. 1994. Dimanika Sistem Pendidikan Pesantren: Suatu Kajian tentang Unsur dan Nilai Sistem Pendidikan Pesantren. Jakarta: INIS.

Milan, Gliuseppe. 2000. Educare all'incotro la edagoia di martin buber. Cittanuova.

Moleong, Lexy J. 2004. Metodologi Penelitian Kualitatif. Bandung: PT. Remaja Rosdakarya.

Purwoko, Saktiyono B. 2012. Psikologi Islami Teori dan Penelitian. Bandung: Saktiyono Press.

Qomar, Mujamil. 2007. Pesantren dari Transformasi Metodologi Menuju Demokatisasi Institusi, Jakarta: Penerbit Erlangga.

Siraj, Said Aqil. 2005. Visi Pesantren Masa Depan (Makalah Seminar Nasional: Musabaqah al-Qur'an Nasional V Telkom).

Soebahar, Abd. Halim. 2013. Modernisasi Pesantren: Transformasi Kepemimpinan Kiai dalam Sistem Pendidikan Pesantren. Yogyakarta: PT. LKIS Printing Cemerlang. 
Sukanto, Surjono. 1982. Sosiologi suatu Pengantar. Jakarta: UI Press.

Sukidi. 1998. Membangun Masyarakat Madani, KOMPAS, 19 April 1998.

Tilaar, H.A.R. 1998. Beberapa Agenda Reformasi Pendidikan Nasional Magelang: Tera Indonesia.

Wahid, Abdurrahman. 1981. Bunga Rampai Pesantren. Jakarta: CV Dharma Bhakti.

Widyatmadja, Josef P. 2009. Kebebasan dan Globalisasi dalam Diplomasi Yogyakarta: Penerbit Kanisius.

Wirawan, I.B. 2015. Teori-teori Sosial dalam Tiga Paradigma, Fakta Sosial, Definisi Sosial, dan Perilaku Sosial. Jakarta: Prenandamedia Group.

Yinger, J. Milton. 1970. The Scientific Study Religion. New York: Macmillan. 